\title{
Front Matter: Volume 11537
}

, "Front Matter: Volume 11537," Proc. SPIE 11537, Electro-Optical and Infrared Systems: Technology and Applications XVII, 1153701 (6 October 2020); doi: $10.1117 / 12.2584623$

SPIE. Event: SPIE Security + Defence, 2020, Online Only 


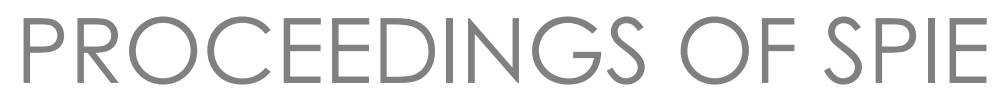

\title{
Electro-Optical and Infrared Systems: Technology and Applications XVII
}

\author{
Duncan L. Hickman \\ Helge Bürsing \\ Editors
}

21 - 25 September 2020

Online Only, United Kingdom

Sponsored by

SPIE

Cooperating Organisations

European Optical Society

Cranfield University (United Kingdom)

Technology Scotland (United Kingdom)

Visit Scotland (United Kingdom)

CENSIS (United Kingdom)

Published by

SPIE 
The papers in this volume were part of the technical conference cited on the cover and title page. Papers were selected and subject to review by the editors and conference program committee. Some conference presentations may not be available for publication. Additional papers and presentation recordings may be available online in the SPIE Digital Library at SPIEDigitalLibrary.org.

The papers reflect the work and thoughts of the authors and are published herein as submitted. The publisher is not responsible for the validity of the information or for any outcomes resulting from reliance thereon.

Please use the following format to cite material from these proceedings:

Author(s), "Title of Paper," in Electro-Optical and Infrared Systems: Technology and Applications XVII, edited by Duncan L. Hickman, Helge Bürsing, Proceedings of SPIE Vol. 11537 (SPIE, Bellingham, WA, 2020) Seven-digit Article CID Number.

ISSN: 0277-786X

ISSN: 1996-756X (electronic)

ISBN: 9781510638877

ISBN: 9781510638884 (electronic)

Published by

SPIE

P.O. Box 10, Bellingham, Washington 98227-0010 USA

Telephone +1 3606763290 (Pacific Time) · Fax +1 3606471445

SPIE.org

Copyright (c) 2020, Society of Photo-Optical Instrumentation Engineers.

Copying of material in this book for internal or personal use, or for the internal or personal use of specific clients, beyond the fair use provisions granted by the U.S. Copyright Law is authorized by SPIE subject to payment of copying fees. The Transactional Reporting Service base fee for this volume is $\$ 21.00$ per article (or portion thereof), which should be paid directly to the Copyright Clearance Center (CCC), 222 Rosewood Drive, Danvers, MA 01923. Payment may also be made electronically through CCC Online at copyright.com. Other copying for republication, resale, advertising or promotion, or any form of systematic or multiple reproduction of any material in this book is prohibited except with permission in writing from the publisher. The CCC fee code is $0277-$ $786 \mathrm{X} / 20 / \$ 21.00$.

Printed in the United States of America by Curran Associates, Inc., under license from SPIE.

Publication of record for individual papers is online in the SPIE Digital Library.

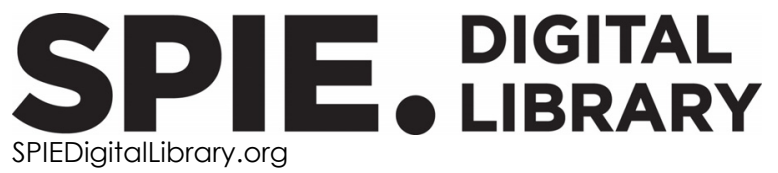

Paper Numbering: Proceedings of SPIE follow an e-First publication model. A unique citation identifier (CID) number is assigned to each article at the time of publication. Utilization of CIDs allows articles to be fully citable as soon as they are published online, and connects the same identifier to all online and print versions of the publication. SPIE uses a seven-digit CID article numbering system structured as follows:

- The first five digits correspond to the SPIE volume number.

- The last two digits indicate publication order within the volume using a Base 36 numbering system employing both numerals and letters. These two-number sets start with $00,01,02,03,04$, 05, 06, 07, 08, 09, OA, OB ... 0Z, followed by 10-1Z, 20-2Z, etc. The CID Number appears on each page of the manuscript. 


\section{Contents}

\section{SENSOR TECHNOLOGY AND DEVICES}

1153704 Scalable nanotube-microbolometer technology with pixel pitches from 12 down to $6 \mu \mathrm{m}$ [11537-3]

SYSTEMS AND APPLICATIONS

1153706 Assessment of new camouflage prototypes deployed in semi-desertic environments using hyperspectral polarimetric imaging sensors (Invited Paper) [11537-5]

1153707 Compact static Fourier transform spectrometer for time-resolved mid-infrared spectroscopy [11537-6]

MODELLING AND SIMULATION

$11537 \mathrm{OA}$ Atmospheric dispersion in oblique imaging from an airborne plafform [1 1537-9]

$11537 \mathrm{OB} \quad$ Improved modulation transfer function evaluation method of a camera at any field point with a scanning tilted knife edge [11537-10]

11537 OC Multi-level fractal test target: corner-point criterion for evaluating visible and digital fusion imagers [11537-11]

11537 OD Performance estimation of a real-time rosette imager [11537-12]

PROCESSING AND ANALYSIS I

$115370 \mathrm{OE} \quad$ Assessing handheld object ID performance of digital night vision VNIR/LWIR fusion (Invited Paper) [11537-13]

11537 OG An efficient low-cost calibration board for long-wave infrared (LWIR) camera [11537-15]

$11537 \mathrm{OH} \quad$ Colour fusion of RGB and NIR imagery for surveillance applications [11537-16]

FUTURE EOIR FOR DEFENCE

11537 0J Development of III-V barrier diode radiation-hard infrared detectors for space applications [11537-18] 
11537 OK Coherence imaging for laser detection [11537-19]

$11537 \mathrm{OL} \quad$ All-optical modulator for gated range finding and active imaging in LWIR [1 1537-20]

11537 OM High Pixel Acquisition Rate (HiPAR) lidar [1 1537-21]

POSTER SESSION

$115370 Q \quad$ Preliminary analysis of shooting training systems: SPARTAN [1 1537-25]

11537 OR Tolerance analysis of wide field of view confocal off-axis telescope system using freeform mirrors for common optics MWIR/LWIR sensors onboard UAVs: linear astigmatism free three mirror system D70F1.4 [11537-26]

11537 OT Methods of distinction of an object observed by thermal imager [11537-28] 